\title{
A conceptual article on strike prone behaviour among labour union members
}

\author{
Amal Tom Jose ${ }^{1, *}$, K. N. Jayakumar ${ }^{2}$ \\ ${ }^{1}$ Research Scholar, ${ }^{2}$ Assistant Professor, Dept. of Psycology, Periyar University, Salem, Tamil Nadu, India
}

*Corresponding Author:

Email: amaltomkolothu3@gmail.com

\begin{abstract}
Abstract: Strike acts as a defensive tool in the hands of employees when they feel exploited by their management. It empowers the employees to have a say in what is decided for them in an industry. Strike, generally involves quitting of work by a group of workers for the purpose of influencing their employer or management to protect their common interest in the organization. When the labour unions or workers collectively cease to work in a particular industry, they are said to be on strike. A strike usually takes place in response to employees' unmet grievances. Strike can cause huge losses for the organization. Strike propensity is different from actual strike. Strike propensity is the extent to which workers are willing to engage in strike. It is a strong predictor of actual strike action. This paper explores the significance and consequence of understanding strike propensity of the employees in workplace and further tries to explore it's relevance in today's volatile organizations.
\end{abstract}

Keywords: Strike, Strike Propensity, Labour union, Employee grievances.

\section{Introduction}

The economic success of any nation depends on the growth of GDP of that country. Increased GDP is based on the healthy economic activity carried out by the industries. An effective industry means peace and harmony in the organization. The success and failure of organizations depends on the nature of workforce. Workforce is the main resource for the organization to carry out its objectives and achieve its purpose. Workforce or Human resources are the indispensable part of any organizational or industrial field. It can either become an asset or liability for the company based on how it is understood and dealt with. In a study, Watson (1999) discovered five areas that are involved in effective human resource practices. They are 1) recruiting excellence; 2) clear rewards and accountability; 3) collegial, flexible workplace; 4) communication integrity; 5) prudent use of resources. An effective human resources practices lead to better financial outcomes and maintaining a healthy employer-employee relationship is crucial for the organization's success. Contrary to this understanding, the management of the organizations focus is primarily on maximizing the profit for the company and little attention has been paid to the human resources. The negligence of the employees in the organization could result in grievances and dissatisfaction among them. This brings in a ground for breeding conflict of interests. Fajana (2000) viewed industrial conflict as inability of parties either between employer and employees or within their groups to reach on an agreement connected with the object of employeremployee interaction, irrespective of whether this inability results in strikes, lockouts or any other form of protest or not. One of the ways in which the employees express their discontentment is through strike. Strike as defined by section 37 (1) of Indian trade dispute Act No 7,1976 is a cessation of work by a body of employed persons acting in combination or a concerned refusal under a common understanding of any number of employed persons to continue to work for an employer inconsequence of a dispute, done as a means of compelling their employer on any person or body of persons employed to aid other workers. The people who engage in strike are called as strikers.

\section{Strike as a Need Gratifying Tool}

Strike is a powerful weapon that is used by the employees and labours or trade unions for attaining or satisfying their needs from the management. It involves quitting of work by labour unions or group of workers. They involve in collective bargaining to get their demands accepted by the authority. One of the major causes of incessant strike actions is the poor application of collective bargaining. This is inevitable for settling industrial conflicts and resolving disputes (Adavbiele, 2015).

Strikes have been used as an instrument by the union leaders to notify the management about their grievances and working conditions (Adavbiele, 2015). According to Adebayo (n.d.), organizational effectiveness is hampered by employee dissatisfaction which resulted in strike. Blyton (2008) revealed that employees do not put up their best performances at workplaces when the employees are not happy with the management, government, or even with their colleagues. Employees having an unpleasant relationship with employer results in strike actions and lockouts. All these negative actions carried out by employees in order to make sure that harm is done to the organization than good, as productivity will be reduced drastically. According to India Risk Survey 2014 published by a lobby group named Federation of Indian Chamber of Commerce and Industry (FICCI) and risk analysis firm Pinkerton, strikes, closures and unrests have been rated as the second biggest risk, after 
corruption, bribery and corporate frauds during the year 2014.

\section{Antecedents of Strike Propensity}

Union commitment is one of the factors that are involved in strike propensity. Cohen (1992) found that union commitment is one of the predictors of strike propensity, irrespective of the goal in which they engage in strike. Several studies found that employees with more positive attitude towards their employer showed less strike prone behavior (Barling et al., 1992; McClendon and Klaas, 1993; Ng, 1991; Martin, 1986). According to Tetrick (1995), a psychological contract is developed among union members who include perceived obligations to the unions and beliefs about the union's responsibilities to them. A strong bond with the union develops stronger obligations which in turn promote their willingness to strike (Barling et.al., 1992). Company commitment plays another major role in the strike propensity of employees. Martin and Berthiaume (1995) revealed that employers who support strikes are more likely to have low company commitment.

Employees belonging to lower economic strata and less economic resource are more likely to consider strike as necessary to protect their economic interest (Cohen, 1992; Martin 1986; Schutt 1982). It is found that there is a negative relationship between strike propensity and pay satisfaction for lower paid employees (Cohen, 1992). Employers who felt that their pay is inequitable are more willing to strike when compared to employees who perceive their pay equitable (Marin, 1986). According to the militancy perspective, younger, less senior, less educated and from a blue collar background are more willing to engage in strike.

\section{Consequences of Strike}

Strike has become a part and parcel of common people's life especially in Kerala. It is one of the favoured methods of protest in Kerala. As the strike increases, the government has to face both financial and economic loss. A media report by 'news18.com' (Sept 2 , 2015) reported that the strike by ten trade unions against changes in labour laws and privatization of public sector undertaking (PSUs) affected transport and banking operations. Train services and road transportation were shut; shops and business establishments were closed down. This hampers the peaceful lives of common people. Shenoy Karun (Jun 11, 2013) reported for Times of India that the Council of the Confederation of Indian Industry (CII) estimated that when hartal is completely successful, there is GDP loss of 900 crores per day, which includes losses from trading, manufacturing and service sectors. In a report by Ameerudheen (April 30, 2017), the reporter mentioned a statistics compiled by Hartal Virudha Munnani (anti-hartal front), in the seven year period between 2005 and 2012, the number of hartal Kerala has 363witnessed in which 184 happened in 2008 alone. So the menace caused by the unreasonable strike needs to be addressed not only in the state of Kerala, but throughout the country.

\section{Concept of Strike in Psychological Literature}

Reviewing the psychological studies relevant to employee strike behavior, it was found that the concept of strike was studied in various contexts and that too were limited in numbers. Some of the studies were listed below in gist.

1. Strike propensity is a motivational concept reflecting the extent to which union members are willing to strike in support of goals articulated by the unions (Barling et al., 1992). Strike propensity means willingness to engage in strike action, it is distinct from actual strike behaviour but it is considered as a strong strike predictor of an employees and trade unions.

2. Union commitment is considered as one of the predictors of strike propensity. According to Hirschman's (1970), the committed members of union are loyal and are active in their union activity. They may not exit from the union and they show more propensity to do strike compared to less committed employees.

3. Barling, Fullagar, Kelloway and McElvie (1992) revealed that there is a weak relationship between union loyalty and strike propensity when the inter role conflict was low.

4. According to Schutt (1982), social-background model many variables play a vital role in causing strike. Strong evidence evolved to suggest that younger and newly joined employees showed more strike prone behaviour especially for increasing their wage and other benefits when compared to senior employees. Another variable that is associated with strike propensity is union participation. He argued that the male employees are more participative in union activities and showed more strike prone behaviour than female employees.

5. A study by Keating (2013) explained that openness to experience; neuroticism and agreeableness were found to be significant factors with regards to strike propensity among Big five factors. But in another study by Brandstatter and Opp (2013), there is no main effect of extraversion in predicting protests, but neurotic extraverts exhibited the higher strike prone behaviour and lowest strike prone behaviour was expressed by the neurotic introverts.

\section{Significance of Strike Propensity in Understanding Employee Strike in India}

Strike propensity is the one of major cause of strike. Although strike propensity does not always imply actual strike action, it is a strong antecedent of it 
(Barling et al. 1992). Having a knowledge regarding the strike propensity of the employees will help the management to negotiate with the employees directly or through indirect means like labour unions. Through this process, they reach at a consensus while avoiding arguments and conflicts. This would prevent the potential damages that would be caused by the strike. If the management knows that a union is under exogenous, identity related or political pressure to strike, then it can infer that merely offering wage concession equal to union's economic costs of striking will not be sufficient to avoid a stoppage (Cohn, 1993).

As the strike involves huge economic and industrial losses, it has to be prevented. One of the effective methods to prevent strike is to participate in sophisticated mutual gain negotiation by the employers and union parties who negotiate for mutual gain, acknowledge their dependence and their independence and accept that they have overlapping and different interests. Their agreement also include mutual commitment to freedom of association, good faith bargaining, exhaustion of dispute producers, democracy, picket rules and non-violence (Brand, 2010).

\section{Strike and Trade Union in the Present Context}

The nature of strike has undergone many changes in the recent past. When compared to the state level strike, the district and municipality level of strikes have skyrocketed in incidences. The High Court of Kerala has given a judgment that calling and holding of bandhs are illegal and unconstitutional. The Kerala High court further ordered that the losses suffered due to the destruction during bandh has to be compensated by the organizers of the bandhs. The Chairman of Confederation of Indian Industry (CII), stated that frequent bandhs are responsible for slow industrialization of the state and the growth of unemployment (Radhakrishnan, 1997). As the informalisation of workforce and downsizing in the industries increased, the trade unions lost their powers drastically. Trade unions represent the interest of formal workers, but the numbers of informal workers are increasing by the day, and the formal workers have become a minority. This resulted in individualized bargaining. Individualized bargaining along with high level of informalisation has altered the nature of trade unions. This converted many trade unions into legal consultants rather than collective bargaining agents. In today's scenario, there is a need to organize the vast masses of unorganized workers into the field of unions. It is not fair to exclude unorganized contract workers as very few protest can achieve victory (Radical Socialist, 2015). The adverse effects caused by strike is invariably huge. Assessing the strike propensity of the employees help the management to prevent the occurrences of strike. Negotiation and collective bargaining proved to be better measures against strike for both the employees and employers. It is the rapport between the employer and employee that enhance their organizations growth. Developing and maintaining healthy relationship with the employer is highly required at this point of time for the betterment of the organization.

\section{Conclusion}

Understanding the employee's propensity to protest would help the employers to provide them with the basic facilities and thus rule out strike. As lack of company commitment, negative attitude towards employers, lack of pay satisfaction, and lack of favorable working condition triggers an employee to engage in strike. Improving these areas could reduce the employees' willingness to engage in strike and thereby inhibit the negative consequences of strike. A person high on strike propensity has high probability of engaging in strike. Considering the negative aspect of strike, it would be better for the employers to assess strike propensity of the employees in the organization and take necessary preventive measures to avoid it. Strikes and the work place social and psychological climate prevailing before the employees take part in strike have a significant ill effect on the mental health of the employees. In order to prevent strikes from happening, management needs to promote the wellbeing and the mental health of the employees. Because employees' mental health has both the direct and indirect impact on the output of the industry. Knowing this the WHO (World Health Organization) has decided the theme 'Mental Health in Workplace' for the year 2017 to be observed on October $10^{\text {th }}$ of 2017. WHO wanted all the places of work to be conducive to mental health and suggested them to involve in all exercise that leads to promotion of employee's mental health and reduction of stress and conflict.

\section{References}

1. Adavbiele, J. A. (2015). Implications of Incessant Strike Actions on the Implementation of Technical Education Programme in Nigeria. Journal of Education and Practice, $134 / 138$

2. Adebayo, A. Y. Effect of Industrial Conflict on Organisational Productivity: A Case Study of Nasco Company of Nigeria.

3. Ameerudheen, T.A. (2017, April 30). ON STRIKE Kerala has seen 27 hartals in four months (And BJP has called 12 of them). Retrived from https://scroll.in/article/835983/kerala-has-seen-27-hartalsin-four-months-and-bjp-has-called-12-of-q them.

4. Arun, M.G. (2014, March 25). Corruption, corporate frauds biggest risks in 2014: FICCI survey. Business, News - India Today, p. 1/2.

5. Employee Relations And It Effects On Organizational Performance. (2013). Retrieved from: researchClue.com... Home for Nigerian Researchers:employee\%20relations $\% 20$ and $\% 20$ it $\% 20 \mathrm{e}$ ffects\%20on\%20organizational\%20performance html. 
6. Industrial Unrest Past Trend \& Lessons For Future. (2012). Retrieved from: Industry's Voice for Policy Change: http://ficci.in/spdocument/20188/industrialunrest.pdf

7. Industrial Unrest Past Trend \& Lessons For Future.

(2012, February). Retrieved from: All India Organisation of Employers (AIOE): http://ficci.in/spdocument/20188/industrial-unrest. pdf

8. Keating, J. (2013, August 27). Are Extroverts More Likely to Protest?. The World. Retrieved from: http://www.slate.com/ blogs/the_world_/2013/08/27/extroversion_and_political _protests_a_surprising_study_on_th

e_link_between.html

9. Labour Strike|Reasons of Strikes | Types of Strikes. (2017, July 11). Retrieved from NaukriHub: http://www.naukrihub.com/industrialrelations

10. Martin, J. E., \& Sinclair, R. R. (2001). A multiple motive perspective on strike propensities. Journal of Organizational Behavior, 22(4), 387-407.

11. Radhakrishnan, M. (1997, August 11). Striking at closures Kerala High Court bans bandhs, political parties and other organisations disappointed : Kerala. India Today, p. 1/5. Retrieved from Kerala High Court bans bandhs, political parties and other organisations disappointed : Kerala.

12. Shenoy, K. (2013, July 11). Hartal numbs Kerala's economy. Retrieved from Indiatimes|The Times of India|The Economic TimesSign.

13. Strikes ( Factory or Industry) lDefinition of Strike 1 Types of Strike - Legal provision of strike. (2017, July 11). Retrieved from: Website on HRM for Students: Retrieved from http://www.whatishumanresource.com/strikes

14. Trade Union strike affects rail, road, bank services across Kerala, Tamil Nadu, Delhi, violent clashes reported in West Bengal. (2015, September 2). NEWS18, p. 1/21. 